\title{
Analisis Ekonomi Penggemukan Sapi Aceh Jantan yang diberikan Substitusi Rumput Gajah dengan Eceng Gondok Fermentasi
}

\author{
(Economic Analysis of Aceh Bulls That Using Elephant Grass \\ as Substitution of Water Hyacinth) \\ Marbawi ${ }^{1}$ Mahyuddin ${ }^{2}$, Didy Rachmadi², \\ ${ }^{1}$ Mahasiswa Program Studi Peternakan, Fakultas Pertanian, Universitas Syiah Kuala \\ ${ }^{2}$ Dosen Program Studi Peternakan, Fakultas Pertanian, Universitas Syiah Kuala
}

\begin{abstract}
Abstrak. Penelitian tentang analisis ekonomi penggemukan sapi Aceh jantan yang diberi pakan substitusi rumput gajah dengan enceng gondok fermentasi telah dilakukan di Laboratorium Lapangan Peternakan (LLP) Prodi Peternakan Fakultas Pertanian Universitas Syiah Kuala. Penelitian ini berlangsung selama 112 hari dari tanggal 24 Januari 2016 - 08 Mei 2016. Tujuan penelitian ini adalah untuk mengetahui pengaruh pemberian pakan substitusi rumput gajah dengan eceng gondok fermentasi terhadap efesiensi ekonomi pemeliharaan ternak sapi lokal Aceh. Materi penelitian ini adalah 4 ekor sapi Aceh jantan dan menggunakan Rancangan Bujur Sangkar Latin (RBSL), yang terdiri dari 4 perlakuan dan 4 ulangan, masing-masing perlakuan adalah pelakuan A (60\% rumput gajah dan $0 \%$ eceng gondok fermentasi) perlakuan B (50\% rumput gajah dan $10 \%$ eceng gondok fermentasi), perlakuan C (40\% rumput gajah dan $20 \%$ eceng gondok fermentasi), dan pelakuan D (30\% rumput gajah dan 30\% eceng gondok fermentasi). Data penelitian yang diperoleh dianalisis menggunakan ANOVA (Analysis of Variance). Parameter yang diamati adalah : Pertambahan Berat badan, Konsumsi Pakan, Biaya produksi, Hasil Produksi, Penerimaan dan Pendapatan. Hasil analisis sidik ragam menunjukkan perbedaan yang sangat nyata terhadap konsumsi pakan $(\mathrm{p}<0,01)$, sedangkan pertambahan berat badan menunjukkan perbedaan yang nyata $(\mathrm{p}<0,05)$. Biaya produksi pada perlakuan A (13.720.409), perlakuan B (13.642.484), perlakuan C (13.589.069) dan perlakuan D (13.514.270). Hasil produksi pada perlakuan A $(287,25)$, perlakuan B $(281,25)$, perlakuan C $(278,25)$ dan perlakuan D $(270,25)$. Penerimaan pada perlakuan A (14.362.500), perlakuan B (14.062.500), perlakuan C (13.912.500) dan perlakuan D (13.512.500). Pendapatan pada perlakuan A ( 642.091), perlakuan B (420.016), perlakuan C (323.431) dan perlakuan D ( -1.770$)$. B/C Ratio perlakuan A $(0,05)$, perlakuan B $(0,3)$, perlakuan $\mathrm{C}(0,02)$ dan perlakuan $\mathrm{D}(-0,00001)$. Hasil penelitian ini menunjukkan bahwa tingkat substitusi yang masih layak digunakan yaitu perlakuan B ( $10 \%$ eceng gondok) dan perlakuan C ( $20 \%$ eceng gondok), sedangkan tingkat substitusi $30 \%$ eceng gondok hasilnya negatif.
\end{abstract}

Kata Kunci : Sapi Aceh Jantan, Eceng gondok fermentasi, Penggemukan, Keuntungan

\begin{abstract}
The research studied abaut on economic analysis of fattening the Aceh bull using the substitution of elephant grass with the fermentation of water hyacinth had been done in the Laboratory of Animal Husbandry, Study Program of Agriculture Faculty Syiah Kuala University. This research had been done for 112 days, from January 24 to May 8 2016. The purpose of this research is to know the influence of giving pasture grass for cattle feed substitution of elephant grass with fermentation of water hyacinth to the efficiency of caring Aceh bull. The material of this research was taken from four Aceh bulls and using Latin Square design (LSD) which consists of 4 characteristics and 4 repetitions. Each of its characteristic A (60\% elephant grass and $0 \%$ is fermentation of water hyacinth), the characteristic B (50\% elephant grass and 10\% is fermentation of water hyacinth), the character C (40\% elephant grass and $20 \%$ is fermentation of water hyacinth), and character D (30\% elephant grass and 30\% water hyacinth fermentation). The research data gained was analyzed using Analysis of Variance (ANOVA). The parameter were which observed is the increase of weigh, pasture grass for cattle consumption, production cost, production result, receiving and income. The result of analysis variance showed the real difference on pasture grass for cattle consumption $(\mathrm{p}<0,01)$, while the increasing of body weigh shows the real difference $(\mathrm{p}<0,5)$. Production cost on character A (Rp.13.720.409), character B (Rp.13.642.484), character C (Rp.13.589.069), and character D (Rp.13.514.270). The result production on character A $(287,25 \mathrm{~kg})$, character B $(281,25 \mathrm{~kg})$, character C $(278,25 \mathrm{~kg})$ and character D $(270,25 \mathrm{~kg})$. The receiving on character A (Rp.14.362.500), character B
\end{abstract}


(Rp.14.062.500) character C (Rp.13.912.500) and character D (Rp.13.512.500). The income on character A (Rp.642.091), character B (Rp.420.016, character C (Rp.323.431) and character D (Rp.-1.770). B/C Character Ratio A $(0,05)$, character B $(0,3)$, character C $(0,02)$ and character D ($0,00001)$. The result of this research shows that the rate of substitution which still can be used is character B (10\% water hyacinth) and character C (20\% water hyacinth), while the rate of substitution is $30 \%$ water hyacinth with negative result.

Key Word : Aceh bull, fermentation of water hyacinth, fattening, and profit

\section{PENDAHULUAN}

Usaha peternakan di Provinsi Aceh secara umum dilakukan secara turun temurun dalam skala rumah tangga. Sama seperti peternak lokal pada umumnya, peternak Aceh memanfaatkan usaha ternak sapi Aceh sebagai tabungan dan belum seperti usaha peternakan skala industri. Meskipun demikian, usaha peternak lokal dengan skala kecil telah memberikan kontribusi yang relatif besar dalam menunjang kebutuhan daging di Provinsi Aceh.

Ada tiga faktor utama yang perlu diperhatikan dalam peningkatan produksi daging sapi, yaitu bibit, pakan dan manajemen usaha. Pakan merupakan faktor yang paling besar pengaruhnya dalam proses produksi usaha peternakan. Tiga hal yang perlu diperhatikan dalam penyediaan pakan yaitu kuantitas, kualitas dan harga pakan. Di Indonesia bahan pakan sapi banyak tersedia, namun dalam penyediaannya masih menghadapi masalah, diantaranya penyempitan lahan padang penggembalaan, persaingan bahan baku pakan untuk kebutuhan lain, kandungan nutrisi yang rendah, teknologi pengolahan terbatas, industri dan sistem distribusi masih sangat terbatas. (Yusdja dan Pasandaran, 2005).

Ketersediaan hijauan pakan untuk ruminansia dimusim kemarau sangat terbatas. Oleh karena itu, perlu adanya upaya pencarian pakan alternatif yang tersedia melimpah sepanjang tahun. Salah satunya yaitu pemanfaatan eceng gondok yang selama ini dikenal sebagai gulma. Eceng gondok yang mempunyai pertumbuhan sangat cepat dikhawatirkan dapat mengganggu fungsi perairan umum. Sebenarnya eceng gondok (Eichhornia crassipes) muda mempunyai kualitas yang baik sebagai pengganti pakan hijauan untuk ternak ruminansia.

\section{MATERI DAN METODE PENELITIAN}

Penelitian ini dilaksanakan di Laboratorium Lapangan Peternakan (LLP) Program Studi Peternakan Fakultas Pertanian Universitas Syiah Kuala Darussalam Banda Aceh. Penelitian ini berlangsung dari tanggal 17 Januari s/d 08 Mei 2016.

\section{Bahan dan Alat}

Bahan bahan yang digunakan dalam penelitian ini adalah: rumput gajah, rumput lapangan, eceng gondok, Aspergillus niger, daun Lamtoro, dedak padi dan molases. Sedangkan peralatan yang digunakan dalam penelitian ini adalah : Sekop, Timbangan analog kecil, Gembor, Plastik silo, Sabit, Timbangan digital $600 \mathrm{~kg}$ dan Timba. 


\section{Ransum Penelitian}

Tabel 1. Komposisi Bahan Pakan Penelitian

\begin{tabular}{lcccc}
\hline \multirow{1}{*}{ Bahan Pakan } & \multicolumn{4}{c}{ Ransum } \\
\cline { 2 - 5 } & $\mathbf{A}$ & $\mathbf{B}$ & $\mathbf{C}$ & $\mathbf{D}$ \\
& $(\mathbf{\%})$ & $(\mathbf{\%})$ & $(\boldsymbol{\%})$ & $(\mathbf{\% )})$ \\
\hline Rumput Lapangan & 40 & 40 & 40 & 40 \\
Rumput Gajah & 60 & 50 & 40 & 30 \\
Eceng Gondok Fermentasi & - & 10 & 20 & 30 \\
\hline
\end{tabular}

Tabel 2. Komposisi Nutrisi Bahan Baku Ransum

\begin{tabular}{lccc}
\hline Nutrisi (\%) & Rumput gajah * & $\begin{array}{c}\text { Rumput } \\
\text { lapangan** }\end{array}$ & $\begin{array}{c}\text { Eceng gondok } \\
\text { fermentasi*** }\end{array}$ \\
\hline Bahan Kering & 19,9 & 22,97 & 40,81 \\
Protein Kasar & 10,2 & 6,69 & 13,35 \\
Serak Kasar & 34,2 & 34,19 & 19,67 \\
Lemak & 1,6 & 1,78 & 0,9 \\
Abu & 11,7 & 9,70 & 12,6 \\
BETN & 42,3 & 47,64 & 57 \\
\hline
\end{tabular}

Sumber : Rukmana, (2005) *, Rahmawati et al., (2000)** dan Mangisah et al., (2003)

Tabel 3. Komposisi Nutrisi Dari Masing-Masing Perlakuaan

\begin{tabular}{ccccccc}
\hline & \multicolumn{6}{c}{ Komposisi Nutrisi Pakan Perlakuan } \\
\cline { 2 - 7 } Pakan Perlakuan & $\begin{array}{c}\text { Bahan } \\
\text { Kering } \\
(\boldsymbol{\%})\end{array}$ & $\begin{array}{c}\text { Protein } \\
\text { Kasar } \\
(\boldsymbol{\%})\end{array}$ & $\begin{array}{c}\text { Lemak } \\
\text { Kasar } \\
(\boldsymbol{\%})\end{array}$ & $\begin{array}{c}\text { Serat } \\
\text { Kasar } \\
(\boldsymbol{\%})\end{array}$ & $\begin{array}{c}\text { BETN } \\
(\boldsymbol{\%})\end{array}$ & $\begin{array}{c}\text { TDN } \\
(\boldsymbol{\%})\end{array}$ \\
\hline A & 24,15 & 6,52 & 0,81 & 33,34 & 48,46 & 53,52 \\
B & 22,36 & 7,21 & 0,88 & 32,03 & 49,26 & 54,55 \\
C & 20,56 & 7,91 & 0,96 & 30,72 & 50,06 & 55,57 \\
D & 18,77 & 8,60 & 1,03 & 29,41 & 50,86 & 56,59 \\
\hline
\end{tabular}

Sumber: Hasil perhitungan dengan Excel

\section{Rancangan Penelitian}

Rancangan yang digunakan dalam penelitian ini adalah Rancangan Bujur Sangkar Latin (RBSL) 4 x 4 menurut Steel dan Torrie (1993).

Tabel 4. Rancangan Penelitian Bujur Sangkar Latin

\begin{tabular}{ccccc}
\hline \multirow{2}{*}{ Periode } & \multicolumn{5}{c}{ Sapi } \\
\cline { 2 - 5 } & $\mathbf{1}$ & $\mathbf{2}$ & $\mathbf{3}$ & $\mathbf{4}$ \\
\hline I & A & B & C & D \\
II & D & A & B & C \\
III & C & D & A & B \\
IV & B & C & D & A \\
\hline
\end{tabular}

Setiap satu ekor sapi mendapat empat perlakuan pemberian ransum selama empat periode.

\section{Pelaksanaan Penelitian}

Sapi-sapi yang dijadikan materi penelitian dipilih terlebih dahulu, pemilihan sapi-sapi ini bertujuan untuk mendapatkan keseragaman antar sapi, baik 
itu jenis kelamin, umur, maupun berat badan sapi, hasil pemilihan di dapatkan umur sapi rata - rata berkisar 2-2,5 tahun, dengan berat badan sapi A $=260 \mathrm{Kg}$, sapi $\mathrm{B}=250 \mathrm{Kg}$, sapi $\mathrm{C}=248 \mathrm{Kg}$ dan sapi $\mathrm{D}=242 \mathrm{Kg}$. Selanjutnya sapi tersebut di adaptasi untuk memudahkan dalam pengumpulan data, guna mengurangi kesalahan dalan analisis data. Adaptasi pemberian pakan dilakukan selama seminggu. Selanjutnya sapi ditimbang untuk mendapatkan data awal berat badan sapi, kemudian dilakukan proses adaptasi terlebih dahulu untuk mempersiapkan sapi menerima perlakuan dari bahan pakan yang diteliti.

Sapi yang dijadikan materi penelitian adalah bangsa sapi Aceh jantan. Pemberian pakan sapi dilakukan pagi hari pukul 08.00-10.00 WIB dan sore hari pukul 16.00-18.00 WIB dengan pemberian kombinasi bahan pakan antara rumput gajah, rumput lapangan dan eceng gondok fermentasi. Air Minum diberikan adlibitum yaitu pemberian air minum tidak dibatasi sehingga sapi dapat minum air setiap saat diperlukan.

\section{Parameter Penelitian}

1. Pertambahan Berat badan

Pertambahan berat badan adalah selisih dari berat badan akhir dikurangi berat badan awal.

2. Konsumsi Pakan

Konsumsi pakan (feed intake) adalah banyaknya bahan pakan yang dapat dikonsumsi oleh ternak selama penelitian. Konsumsi pakan adalah total pakan yang diberikan dikurangi dengan sisa pakan.

3. Biaya produksi

Biaya produksi dihitung dengan cara menjumlahkan seluruh biaya faktorfaktor produksi yaitu biaya tetap dan biaya tidak tetap. Biaya tetap terdiri dari penyusutan kandang, sedangkan biaya tidak tetap terdiri dari biaya pembelian bibit, pengeluaran untuk pembelian bahan-bahan pakan, dan vitamin.

4. Hasil Produksi

Hasil produksi adalah hasil yang diperoleh dari pertambahan berat badan yang merupakan selisih berat badan akhir dikurangi berat badan awal(kg).

5. Nilai Hasil Produksi

Nilai hasil produksi adalah perkalian hasil produksi (berat badan akhir-berat badan awal) dengan harga perkilogram berat hidup yang berdasarkan harga pasar.

6. Keuntungan

Keuntungan merupakan selisih antara nilai hasil produksi (total penerimaan) dengan total pengeluaran yang dinilai dalam satuan rupiah.

\section{Analisa Kelayakan Usaha}

Untuk mengetahui apakah layak tidaknya penggunaan rumput gajah dan eceng gondok fermentasi sebagai pakan substitusi dilakukan Analisis Tingkat keuntungan (TU), Rasio Manfaat Biaya (RMB) dan Break Even Point (BEP).

\section{Analisa Data}

Data pendukung penelitian seperti pertambahan bobot badan, konsumsi pakan dianalisis dengan sidik ragam (Anova/Analisys of variance). Apabila terdapat perbedaan antar perlakuan maka akan dilanjutkan dengan Uji Jarak Berganda Duncan (Duncan Multiple Range Test) 


\section{HASIL DAN PEMBAHASAN}

\section{Konsumsi Pakan}

Konsumsi pakan adalah jumlah pakan yang dimakan oleh ternak yang akan digunakan untuk mencukupi kebutuhan hidup pokok dan produksi. Tilman, dkk (1986) menyatakan bahwa pada bahan kering ransum mengandung karbohidrat, lipida, protein, vitamin dan mineral. Bahan-bahan tersebut sangat berpengaruh untuk pertumbuhan, produksi dan reproduksi ternak. Rataan konsumsi ransum penelitian dapat dilihat pada Tabel 5 berikut.

Tabel 5. Konsumsi Pakan Sapi Aceh Jantan Selama Penelitian (kg/periode/ekor)

\begin{tabular}{|c|c|c|c|c|c|c|}
\hline \multirow{2}{*}{ Periode } & \multicolumn{4}{|c|}{ Perlakuan } & \multirow{2}{*}{ Total } & \multirow{2}{*}{ Rerata } \\
\hline & $\mathrm{A}$ & B & $\mathrm{C}$ & D & & \\
\hline I & 540,36 & 502,63 & 472,70 & 436,31 & 1952,00 & 488,00 \\
\hline II & 528,44 & 485,43 & 450,03 & 418,14 & 1882,04 & 470,51 \\
\hline III & 516,88 & 472,17 & 466,53 & 423,66 & 1879,24 & 469,81 \\
\hline IV & 518,75 & 490,88 & 458,61 & 417,70 & 1885,94 & 471,49 \\
\hline Total & 2104,43 & 1951,11 & 1847,87 & 1695,81 & 7599,22 & \\
\hline Rerata & $526,11^{a}$ & $487,78^{b}$ & $461,97^{c}$ & $423,95^{d}$ & & \\
\hline
\end{tabular}

Ket : Superskrip yang berbeda pada kolom berbeda menunjukkan perbedaan yang sangat nyata $(\mathrm{P}<0,01)$

Tabel 5 menunjukkan bahwa konsumsi ransum sapi Aceh jantan selama penelitian ini yang tertinggi terdapat pada perlakuan A yaitu $2104,43 \mathrm{~kg}$, kemudian diikuti Perlakuan B yaitu 1951,11 kg, perlakuan C yaitu 1847,87 kg dan perlakuan D yaitu $1695,81 \mathrm{~kg}$. Analisis sidik ragam memperlihatkan bahwa penambahan berbagai level eceng godok fermentasi menunjukkan perbedaan yang sangat nyata $(\mathrm{P}<0.01)$ terhadap konsumsi pakan Sapi Aceh jantan.

\section{Pertambahan Berat Badan}

Kemampuan ternak merubah bahan pakan yang dikonsumsi menjadi daging dan lemak badan setelah kebutuhan hidup terpenuhi dengan pertambahan berat badan (Maynard dkk, 1979). Pertambahan berat badan ini juga berkaitan dengan pertumbuhan dimana, pertumbuhan ini adalah perubahan ukuran yang meliputi perubahan berat hidup, bentuk, komposisi tubuh, termasuk perubahan komponen-komponen tubuh seperti otot, lemak, tulang dan organ serta komponen kimia terutama air, lemak, protein dan abu (Soeparno, 1994). Pertambahan berat badan sapi Aceh jantan dapat dilihat pada Tabel 6 berikut. 
Tabel 6. Pertambahan Bobot Badan Sapi Aceh Jantan (Kg/Periode/Ekor)

\begin{tabular}{ccccccc}
\hline \multirow{2}{*}{ Periode } & \multicolumn{9}{c}{ Perlakuan } & \multirow{2}{*}{ Total } & \multirow{2}{*}{ Rerata } \\
\cline { 2 - 5 } & $\mathbf{A}$ & $\mathbf{B}$ & $\mathbf{C}$ & $\mathbf{D}$ & & \\
\hline I & 10 & 8 & 7 & 4 & 29 & 7,25 \\
II & 11 & 8 & 8 & 7 & 34 & 8,5 \\
III & 10 & 8 & 6 & 8 & 32 & 8 \\
IV & 8 & 9 & 9 & 3 & 29 & 7,25 \\
Total & $\mathbf{3 9}$ & $\mathbf{3 3}$ & $\mathbf{3 0}$ & $\mathbf{2 2}$ & $\mathbf{1 2 4}$ & \\
\hline Rerata & $\mathbf{9 , 7 5}^{\mathbf{a}}$ & $\mathbf{8 , 2 5}^{\mathbf{a}}$ & $\mathbf{7 , 5}^{\mathbf{a}}$ & $\mathbf{5 , 5}^{\mathbf{b}}$ & &
\end{tabular}

Ket: Superskrip yang berbeda pada kolom berbeda menunjukkan perbedaan yang nyata $(\mathrm{P}<0,05)$

Tabel 6 menunjukkan bahwa pertambahan berat badan sapi aceh jantan selama penelitian tertiggi terdapat pada perlakuan A yaitu $39 \mathrm{~kg}$, kemudian diikuti perlakuan B yaitu $33 \mathrm{~kg}$, perlakuan C yaitu $30 \mathrm{~kg}$, dan perlakuan D yaitu $22 \mathrm{~kg}$. Hasil analisis keragaman pertambahan berat badan sapi Aceh jantan yang diberi pakan berbasis rumput alam, rumput gajah dan eceng gondok fermentasi menunjukkan hasil perbedaan yang nyata $(\mathrm{p}<0,05)$ antara perlakuan $\mathrm{A}, \mathrm{B}, \mathrm{C}$ dan D.

\section{Biaya Produksi}

Biaya produksi adalah biaya yang harus dikeluarkan untuk memperoleh faktor-faktor produksi dan bahan-bahan penunjang lainnya yang digunakan agar produksi yang diinginkan dapat terwujud dengan baik (Kartasapoetra, 1988).

\section{Total Biaya Produksi}

Total biaya produksi adalah keseluruhan biaya yang dikeluarkan selama penelitian (input) dalam satuan rupiah.

Tabel 8. Total Biaya Produksi Selama Penelitian

\begin{tabular}{|c|c|c|c|c|c|}
\hline \multirow{2}{*}{\multicolumn{2}{|c|}{ Biaya Produksi }} & \multicolumn{4}{|c|}{ Perlakuan } \\
\hline & & $\mathbf{A}$ & B & $\mathbf{C}$ & $\mathbf{D}$ \\
\hline HSB & & 12.412 .500 & 12.412 .500 & 12.412 .500 & 12.412 .500 \\
\hline BR & & 901.411 & 823.486 & 770.071 & 695.272 \\
\hline $\mathrm{BO}$ & & 8.000 & 8.000 & 8.000 & 8.000 \\
\hline UTK & & 367.500 & 367.500 & 367.500 & 367.500 \\
\hline BPP & & 30.998 & 30.998 & 30.998 & 30.998 \\
\hline BPK & & 41.667. & 41.667. & 41.667. & 41.667. \\
\hline Total & & 13.720 .409 & 13.642 .484 & 13.589.069 & 13.514 .270 \\
\hline Keterangan: & $\begin{array}{l}\text { HSB } \\
\text { BR } \\
\text { BO } \\
\text { UTK } \\
\text { BPP } \\
\text { BPK }\end{array}$ & $\begin{array}{l}\text { : Harga sapi } \\
\text { : Biaya ransu } \\
\text { : Biaya obat- } \\
\text { : Upah tenag } \\
\text { : Biaya peny } \\
\text { : Penyusutan }\end{array}$ & $\begin{array}{l}\text { akalan } \\
\text { obatan } \\
\text { kerja } \\
\text { isutan perala } \\
\text { kandang }\end{array}$ & & \\
\hline
\end{tabular}




\section{Hasil Produksi}

Hasil produksi yang dimaksud dalam penelitian ini adalah pertambahan berat badan sapi sebagai akibat dari kemampuan ternak dalam mengubah zat-zat makanan yang dikonsumsi menjadi daging dan lemak badan setelah kebutuhan hidup pokok terpenuhi. Hasil produksi berupa pertambahan berat badan sapi selama penelitian terlihat pada Tabel berikut.

Tabel 9. Hasil Produksi Sapi Aceh Jantan Selama Penelitian

\begin{tabular}{ccccc}
\hline Perlakuan & $\begin{array}{c}\text { Berat Badan } \\
\text { Awal (kg) }\end{array}$ & $\begin{array}{c}\text { PBB Selama } \\
\text { Penelitian }(\mathbf{k g})\end{array}$ & $\begin{array}{c}\text { Berat Badan } \\
\text { Akhir }(\mathbf{k g})\end{array}$ & PBBH \\
\hline A & 248,25 & 39 & 287,25 & 0,464 \\
B & 248,25 & 33 & 281,25 & 0,393 \\
C & 248,25 & 30 & 278,25 & 0,357 \\
D & 248,25 & 22 & 270,25 & 0,262 \\
\hline
\end{tabular}

Tabel 9 diatas dapat dilihat pertambahan berat badan tertinggi terdapat pada sapi A (39 kg). Nilai produksi yang dimaksud dalam penelitian ini adalah nilai akhir ternak sapidari pemeliharaan selama penelitian. Harga sapi dihitung berdasarkan harga jual perkilogram berat hidup, yaitu Rp. 50.000/kg berat hidup.

\section{Penerimaan}

Penerimaan adalah hasil jumlah produksi fisik dikalikan dengan satuan harga produksi (Soekartawi, 1987). Hasil penerimaan pada penelitian ini berat badan akhir ternak dikalikan dengan harga perkilogram berat hidup.

Tabel 10. Total Penerimaan Dari Pertambahan Bobot Badan Selama Penelitian

\begin{tabular}{cccc}
\hline Perlakuan & $\begin{array}{c}\text { Berat Badan } \\
\text { Akhir }(\mathbf{k g})\end{array}$ & $\begin{array}{c}\text { Harga Sapi Per kg } \\
\text { (Bobot Hidup) }\end{array}$ & Penerimaan \\
\hline A & 287,25 & 50.000 & 14.362 .500 \\
B & 281,25 & 50.000 & 14.062 .500 \\
C & 278,25 & 50.000 & 13.912 .500 \\
D & 270,25 & 50.000 & 13.512 .500 \\
\hline
\end{tabular}

Tabel 10 menunjukkan bahwa hasil penerimaan tertinggi terdapat pada perlakuan A. Hal ini disebabkan karena pertambahan berat badan pada perlakuan A sedikit lebih tinggi dari perlakuan yang lain, sehingga berpengaruh langsung terhadap harga jual ternak.

\section{Keuntungan}

Keuntungan yang didapat pada penelitian ini adalah hasil penerimaan dikurangi biaya produksi. Tabel 11 berikut memperlihatkan keuntungan pada pemeliharaan sapi Aceh jantan selama penelitian. 
Tabel 11. Keuntungan Dari Pemeliharaan Sapi Aceh Jantan Selama Penelitian

\begin{tabular}{cccc}
\hline Perlakuan & $\begin{array}{c}\text { Total Penerimaan } \\
(\mathbf{R p})\end{array}$ & $\begin{array}{c}\text { Total Biaya Produksi } \\
(\mathbf{R p})\end{array}$ & Keuntungan \\
\hline A & 14.362 .500 & 13.720 .409 & 642.091 \\
B & 14.062 .500 & 13.642 .484 & 420.016 \\
C & 13.912 .500 & 13.589 .069 & 323.431 \\
D & 13.512 .500 & 13.514 .270 & -1.770 \\
\hline
\end{tabular}

Suatu usaha dikatakan berhasil apabila jumlah pendapatan yang diperoleh lebih besar dari total pengeluarannya (Sudarmono dan Sugeng, 2008). Dalam penelitian ini perlakuan $\mathrm{A}, \mathrm{B}$ dan $\mathrm{C}$ memperoleh penerimaan yang dapat membayar semua biaya produksi dan ada kelebihannya (untung). Keuntungan yang paling tinggi terdapat pada perlakuan A kemudian diikuti oleh perlakuan B dan C. Sedangkan pada perlakuan D pendapatannya minus (rugi).

\section{Analisis Kelayakan Usaha}

Untuk mengetahui kelayakan usaha penggunaan ransum eceng gondok fermentasi dalam ransum sapi Aceh jantan, hasil tersebut dianalisis dengan "analisis tingkat keuntungan (profitabilitas rate), analisis benefit cost ratio dan Break Even Point (BEP)".

\section{a. Analisis keuntungan}

Hasil analisis tingkat keuntungan (TU) dibandingkan dengan tingkat bunga bank yang berlaku dan dinyatakan dalam tingkat keuntungan minimum paling menarik (TKMM). Apabila TU (\%) lebih besar dari TKMM usaha tersebut dinyatakan layak diusahakan, bila TU (\%) sama dengan TKMM maka usaha tersebut impas (pulang pokok), dan bila TU (\%) lebih kecil dari TKMM maka usaha tersebut tidak layak diusahakan. Dalam analisis ini tingkat bunga bank yang dipakai adalah sebesar 15\% pertahun dengan lama pinjaman 90 hari (3 bulan). Untuk mengetahui kelayakan usaha dari pemeliharaan sapi Aceh jantan ini dilakukan analisis tingkat keuntungan (TU), yaitu total keuntungan dibagi total biaya produksi dikali $100 \%$.

Tabel 12. Tingkat Keuntungan yang Diperoleh Selama Penelitian

\begin{tabular}{cccccc}
\hline $\begin{array}{c}\text { Perlakua } \\
\mathbf{n}\end{array}$ & $\begin{array}{c}\text { Total Biaya } \\
\text { Produksi } \\
(\mathbf{R p})\end{array}$ & $\begin{array}{c}\text { Keuntun } \\
\text { gan }\end{array}$ & $\begin{array}{c}\text { Tingkat } \\
\text { Keuntunga } \\
\mathbf{n}(\boldsymbol{\%})\end{array}$ & $\begin{array}{c}\text { TKMM } \\
(\%)\end{array}$ & $\begin{array}{c}\text { Keterang } \\
\text { an }\end{array}$ \\
\hline A & 13.720 .409 & 642.091 & 4,68 & 3,75 & Layak \\
\hline B & 13.642 .484 & 420.016 & 3,08 & 3,75 & $\begin{array}{c}\text { Tidak } \\
\text { Layak }\end{array}$ \\
\hline C & 13.589 .069 & 323.431 & 2,38 & 3,75 & $\begin{array}{c}\text { Tidak } \\
\text { Layak }\end{array}$ \\
\hline D & 13.514 .270 & -1.770 & $-0,01$ & 3,75 & $\begin{array}{c}\text { Tidak } \\
\text { Layak }\end{array}$ \\
\hline
\end{tabular}

Tabel 12 diatas menjelaskan bahwa persentase tingkat keuntungan perlakuan A (4,68 \%) lebih besar dari TKMM (3,75\%) maka dikatakan layak, 
artinya jika usaha ini meminjam modal untuk pengembangan usaha dengan tingkat bunga bank $15 \%$ pertahun maka dengan pendapatan yang diperoleh mampu membayar pinjaman bunga bank $15 \%$. Sedangkan pada perlakuan B $(3,08 \%), \mathrm{C}(2,38 \%)$ dan D (-0,01\%), perlakuan dengan tingkat keuntungan yang negatif dibandingkan dengan TKMM $(3,75 \%)$ dikatakan tidak layak.

b. Analisis benefit cost ratio (analisis rasio manfaat biaya)

Analisis rasio manfaat biaya adalah cara lain untuk menentukan suatu usaha layak atau tidak untuk diusahakan. Jika rasio antara pendapatan dengan biaya produksi lebih besar dari 0 , maka usaha tersebut dapat dilanjutkan karena memberikan hasil yang positif. Sebaliknya, jika rasio antara pendapatan dengan total biaya produksi lebih kecil dari 0, maka usaha tersebut mengalami kerugian, dan jika rasio antara pendapatan dengan total biaya produksi sama dengan 0 , maka usaha tersebut dikatakan impas (pulang pokok).

Tabel 13. Ratio Manfaat Biaya Masing-masing Perlakuan

\begin{tabular}{ccccc}
\hline Perlakuan & $\begin{array}{c}\text { Keuntungan } \\
(\mathbf{R p})\end{array}$ & $\begin{array}{c}\text { Biaya } \\
\text { Produksi }(\mathbf{k g})\end{array}$ & B/C Ratio & Keterangan \\
\hline $\mathrm{A}$ & 642.091 & 13.720 .409 & 0,05 & Layak \\
$\mathrm{B}$ & 420.016 & 13.642 .484 & 0,03 & Layak \\
$\mathrm{C}$ & 323.431 & 13.589 .069 & 0,02 & Layak \\
$\mathrm{D}$ & -1.770 & 13.514 .270 & $-0,00001$ & Tidak Layak \\
\hline
\end{tabular}

Ratio manfaat biaya yang diperoleh semua perlakuan menunjukkan bahwa usaha yang dijalankan memberi hasil yang positif karena berdasarkan perbandingan antara pendapatan dengan biaya produksi lebih besar dari 0 , artinya dengan pendapatan yang diperoleh dapat membayar seluruh biaya produksi dan usaha ini layak dilanjutkan.

c. Break Even Point

Menurut Munawir S (2002) titik break even point titik pulang pokok dapat diartikan sebagai suatu keadaan dimana dalam operasinya perusahaan tidak memperoleh laba dan tidak rugi (total penghasilan = total baya).

Tabel 14. Break Even Point Harga Masing-masing Perlakuan

\begin{tabular}{cccc}
\hline Perlakuan & $\begin{array}{c}\text { Total Biaya } \\
\text { Produksi (Rp) }\end{array}$ & $\begin{array}{c}\text { PBB } \\
\text { Akhir/Perlakuan } \\
(\mathbf{k g})\end{array}$ & $\begin{array}{c}\text { Harga Jual/Kg } \\
\text { Untuk Mencapai } \\
\text { Titik Impas }\end{array}$ \\
\hline A & 13.720 .409 & 287,25 & 47.765 \\
B & 13.642 .484 & 281,25 & 48.507 \\
C & 13.589 .069 & 278,25 & 48.838 \\
D & 13.514 .270 & 270,25 & 50.007 \\
\hline
\end{tabular}

Tabel 14 menunjukkan bahwa untuk mencapai titik impas pada perlakuan A yaitu harga jual/kg Rp. 47.765, Perlakuan B yaitu Rp. 48.507, perlakuan C yaitu Rp. 48.838 dan perlakuan D yaitu Rp.50.007. 
Tabel 15. Break Even Point Produksi Masing-masing Perlakuan

\begin{tabular}{cccc}
\hline Perlakuan & $\begin{array}{c}\text { Total Biaya } \\
\text { Produksi } \\
(\mathbf{R p})\end{array}$ & $\begin{array}{c}\text { Harga Sapi Per kg } \\
\text { (Bobot Hidup) }\end{array}$ & $\begin{array}{c}\text { Jumlah Produk (kg) } \\
\text { Untuk Mencapai Titik } \\
\text { Impas }\end{array}$ \\
\hline A & 13.720 .409 & 50.000 & 274,41 \\
B & 13.642 .484 & 50.000 & 272,85 \\
C & 13.589 .069 & 50.000 & 271,78 \\
D & 13.514 .270 & 50.000 & 270,29 \\
\hline
\end{tabular}

Tabel 15 menunjukkan bahwa untuk mencapai titik impas pada perlakuan A yaitu jumlah produksi yang harus dihasilkan adalah $274,41 \mathrm{~kg}$, perlakuan B yaitu 272,85, perlakuan C yaitu 271,78, dan perlakuan D yaitu 270,29.

\section{KESIMPULAN}

Dari hasil penelitian dapat di simpulkan bahwa :

1. Hasil analisis keragaman menunjukkan bahwa pemberian pakan substitusi eceng gondok fermentasi menunjukkan perbedaan yang sangat nyata $(\mathrm{P}<0.01)$ terhadap konsumsi pakan sapi Aceh jantan.

2. Hasil analisis keragaman menunjukkan bahwa pemberian pakan substitusi eceng gondok fermentasi menunjukkan perbedaan yang nyata $(\mathrm{P}<0.05)$ terhadap pertambahan berat badan sapi Aceh jantan.

3. Total biaya produksi tertinggi terdapat pada perlakuan A. Ini disebabkan karena biaya pakan yang dikonsumsi lebih tinggi dibandingkan perlakuan lainnya.

4. Total penerimaan dari pertambahan berat badan selama penelitian menunjukkan bahwa hasil penerimaan tertinggi terdapat pada perlakuan A yaitu Rp. 14.362.500.

5. Rasio manfaat yang diperoleh perlakuan A $(0,5)$, perlakuan $B(0,3)$, perlakuan C $(0,2)$ menunjukkan bahwa usaha yang dijalankaan ini layak untuk dilanjutkan. Sedangkan perlakuan D (-0,00001) menunjukkan bahwa usaha yang dijalankaan ini rugi.

6. Hasil analisis BEP Harga dapat disimpulkan bahwa untuk mencapai titik impas pada perlakuan A yaitu harga jual/kg Rp. 47.765, Perlakuan B yaitu Rp. 48.507, perlakuan C yaitu Rp. 48.838 dan perlakuan D yaitu Rp.50.007. Sedangkan hasil analisis BEP produksi, untuk mencapai titik impas pada perlakuan A yaitu jumlah produksi yang harus dihasilkan adalah $274,41 \mathrm{~kg}$, perlakuan B yaitu 272,85, perlakuan C yaitu 271,78, dan perlakuan D yaitu 270,29.

7. Hasil penelitian ini menunjukkan bahwa tingkat substitusi rumput gajah dengan eceng gondok fermentasi yang masih layak disubstitusikan adalah pada perlakuan B (10\% eceng gondok) dan perlakuan C (20\% eceng gondok), sedangkan tingkat substitusi yang $30 \%$ eceng gondok hasilnya negatif. 


\section{DAFTAR PUSTAKA}

Fuskhah, E. 2000. Eceng gondok (Eichhornia crassipes (Mart) Solm) sebagai alternatif sumber bahan pakan, industri dan kerajinan. Jurnal Ilmiah Sainteks. Vol 7 (4)

Kadariah. 1999. Evaluasi Proyek Analisis Ekonomi. Lembaga Penelitian Fakultas

Maynard, L.A, J.K. 1979. Animal Nurition 7th ED. Publishing Company Ltd. New Delhi

Munawir, S, 2002. Analisis Laporan Keuangan, Edisi Kedua, YPKN, Yogyakarta. Soekartawi. 1987. Prinsip Dasar Ekonomi Pertanian. Penerbit Rajawali. Jakarta

Soeparno. 1994. Ilmu dan Teknologi Daging. Gadjah Mada University Press. Yogyakarta.

Sudarmono, A.S. dan Sugeng, Y.B. 2008. Sapi Potong. Penebar Swadaya. Semarang

Yusdja, Y. Dan E. Pasandaran. 2005. Keragaan Agrobisnis Tanaman-Ternak. Dalam: Efendi Pasandara, A.M. Fagi Dan Faisal Kasryno. Integrasi Tanaman-Ternak Di Indonesia. Badan Litbang Pertanian. Departemen Pertanian, Jakarta 